Agnieszka Bartoszewicz, Henryk Bartoszewicz

\title{
Obraz kartograficzny miast Królestwa Polskiego $1815-1836$
}

\author{
Słowa kluczowe: Królestwo Polskie, XIX w., Komisja Rządowa Spraw Wewnętrznych i \\ Policji, miasto, plany regulacyjne \\ Key words: Congress Poland, 19th century, Government Commission of Internal \\ Affairs and Police, town, regulation plans
}

W końcu 1815 r. władze Królestwa Polskiego, utworzonego mocą decyzji Kongresu Wiedeńskiego, podjęły działania zmierzające do uporządkowania, regulacji i odbudowy ze zniszczeń wojennych miast pozostających w granicach nowego państwa. 27 listopada 1815 r. powstała Komisja Rządowa Spraw Wewnętrznych i Policji (dalej cyt.: KRSWiP), jako jedna z pięciu, którym powierzono władzę wykonawczą w Królestwie Polskim. KRSWiP kierowała administracją kraju za pośrednictwem Komisji Wojewódzkich. Nadzór nad poprawą kondycji miast sprawował od momentu utworzenia KRSWiP Wydział Administracji ${ }^{1}$.

Jednocześnie przystąpiono do tworzenia prawnych i organizacyjnych podstaw prowadzenia systematycznych pomiarów miast. 13 czerwca 1818 r., na mocy postanowienia namiestnika Królestwa Polskiego, generała Józefa Zajączka, powołano urząd dozorców miast, nakładając na nich m.in. obowiązek zadbania o sporządzanie map miast w granicach zabudowy i miejskiej własności ziemskiej. Urzędnicy ci 24 sierpnia 1819 r. zostali zaopatrzeni w instrukcję nakazującą odnalezienie wszelkiej istniejącej dokumentacji kartograficznej z rejestrami pomiarowymi i planów urbanistycznych oraz zlecenie, za zgodą właściwej Komisji Wojewódzkiej, wykwalifikowanym geometrom dokonania pomiarów tych ośrodków, które nie posiadały stosownych kartografików. Wcześniej, 4 maja 1819 r., rozesłano do Komisji Wojewódzkich instrukcję pomiarową 2 .

Wydarzeniem przełomowym w prowadzeniu prac porządkowych i pomiarowych w miastach Królestwa Polskiego było ustanowienie 4 stycznia 1820 r. Komisji Miast w strukturze KRSWiP. Komórka ta miała nadzorować realizację prac pomiarowych i kartograficznych. W tym celu jej urzędnicy opracowali nową instrukcję pomiarową, ogłoszoną 2 września 1820 r. Natomiast kolejna, również przygotowana przez Komisję Miast, weszła w życie 28 marca 1823 r. i obowiązywała do połowy lat trzydziestych XIX w. Dokument ten przewidywał opracowanie dla każdego ośrodka dwóch map, z których jedna, w skali 1:1500, miała być mapą obszaru zabudowanego, z zaznaczeniem działek, zabudowań, ulic i placów, zaś druga, w skali 1:5000, miała być mapą gruntów miejskich, m.in. ogrodów, pól i pastwisk ${ }^{3}$.

Zalecenia instrukcji z $1823 \mathrm{r}$. nie zawsze były w pełni realizowane. Często, w miejsce odrębnych map obszaru zabudowanego i własności ziemskiej, wykonywano jedną, obejmującą

\footnotetext{
${ }^{1}$ Bartoszewicz A., Bartoszewicz H. 2012, s. 28.

2 Ćwik W. 2001, s. 139-147.

${ }^{3}$ Olszewicz B. 1998, s. 81; Bartoszewicz H. 2012, s. 105-110.
} 


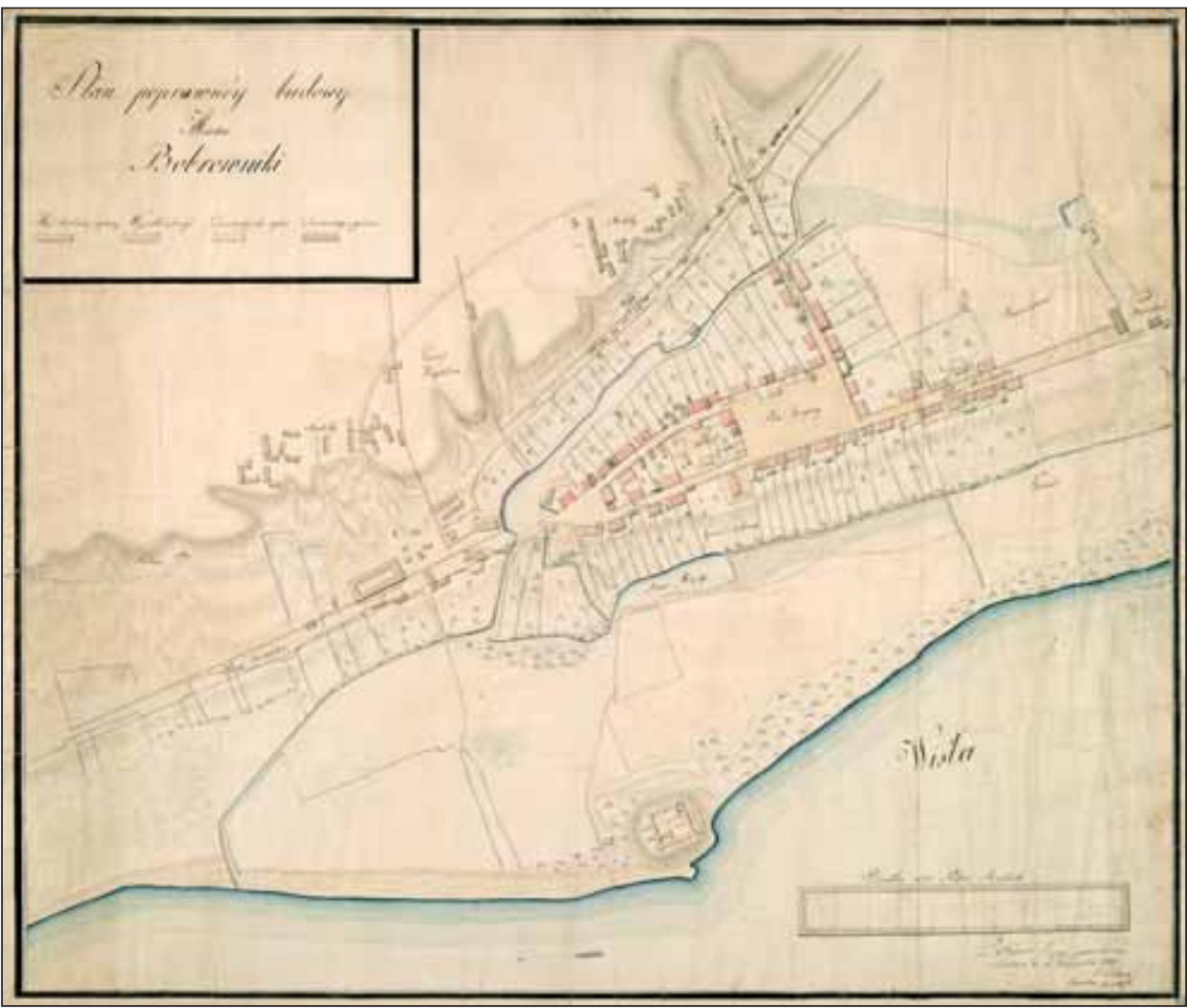

Ryc. 1. Plan sytuacyjno-regulacyjny Bobrownik, 1820 r. (AGAD, Zb. Kart. 186-17)

Fig. 1. A situation-regulation plan of Bobrowniki, 1820 (AGAD, Zb. Kart. 186-17)

zasięgiem terytorialnym miasto i jego grunty. Instrukcja przewidywała też sporządzenie każdej z dwóch map w trzech egzemplarzach; w praktyce najczęściej powstawał tylko jeden. W przypadku niektórych miast Królestwa Polskiego nie sporządzono map ujętych w instrukcji $1823 \mathrm{r}$. Zamiast tworzyć nowe mapy pomiarowe, władze miejskie wykorzystywały materiały kartograficzne pochodzące z czasów przedrozbiorowych, bądź z okresu okupacji pruskiej, mające najczęściej inną skalę niż zalecana przez Komisję Miast. Tak było w przypadku Pułtuska, którego mapa z 1803 r. używana była w okresie Królestwa Polskiego. Przypuszczalnie podobnie postąpiono także m.in. w Dobrzyniu nad Wisłą, Lipnie i Rypinie. Często także uwierzytelniano i aktualizowano pruskie mapy miast polskich, które w latach dwudziestych i trzydziestych XIX w. służyły jako podkład do planów regulacyjnych, jak to miało miejsce w przypadku sporządzonych w 1820 r. w skali ok. 1:2000 planów sytuacyjno-regulacyjnych Bobrownik (ryc. 1) ${ }^{4}$ i Wizny ${ }^{5}$. Wiele miast, mimo posiadania wcześniejszych map ogólnych, wykonało jednak skrupulatnie zalecenia Komisji Miast.

${ }^{4}$ AGAD, Zb. Kart., 186-17. Jest to kopia planu sprzed 1820 r., prawdopodobnie sporządzonego w okresie pruskim (przed 1806 r.), której dokładność poświadczył geometra przysięgły Juliusz Kolberg 18 października 1820 r. w Warszawie.

5 AGAD, Zb. Kart., 347-5b. Plan jest kopią mapy wielkoskalowej Wizny sporządzonej 23 stycznia 1799 r. przez geometrę pruskiego Weishaupta. Dokładność kopii potwierdził 3 września 1820 r. geometra przysięgły Juliusz Kolberg. 


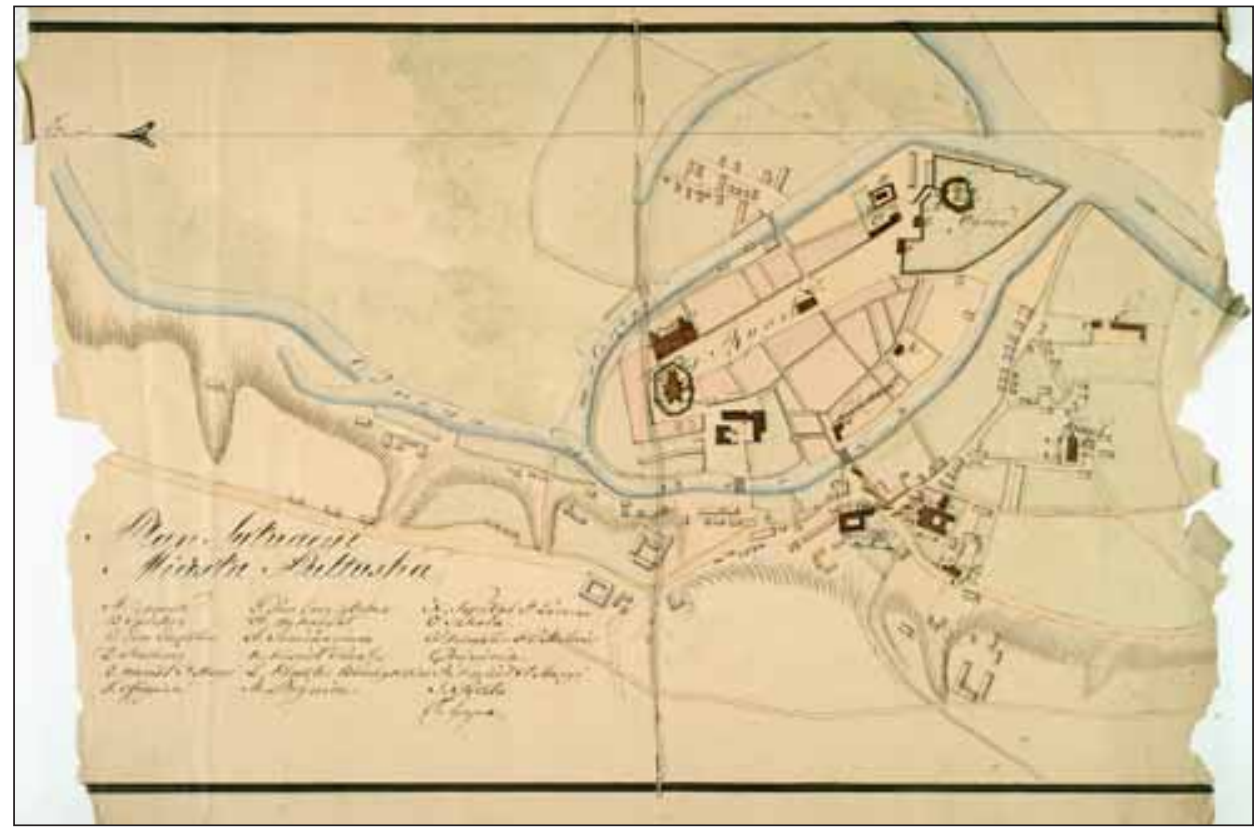

Ryc. 2. Plan sytuacyjny Pułtuska, 1816 r. (AGAD, KRSW 4482, k. 17)

Fig. 2. A situation plan of Pultusk, 1816 (AGAD, KRSW 4482, k. 17)

Pomimo trudności najczęściej natury finansowej w kartowaniu ośrodków miejskich, w okresie obowiązywania instrukcji, czyli do roku 1836, powstały wielkoskalowe mapy pomiarowe ponad 200 spośród ok. 450 miast ówczesnego Królestwa Polskiego ${ }^{6}$. Jednakże wiele z nich zaginęło lub zostało zniszczonych w czasie drugiej wojny światowej, przede wszystkim podczas burzenia przez Niemców stolicy po upadku powstania warszawskiego. W pożarze Archiwum Skarbowego zniszczeniu uległy wówczas m.in. znajdujące się w jego zasobie mapy miast polskich, w tym kartografika miejskie z lat 1815-1836 .

Mapy wielkoskalowe miast Królestwa Polskiego opracowane w okresie konstytucyjnym można podzielić na trzy grupy. Pierwszą, najliczniejszą, stanowią plany sytuacyjne lub sytuacyjno-regulacyjne, które były rezultatem realizacji przez władze municypalne decyzji KRSWiP, a które sporządzano na podstawie kolejnych instrukcji wykonawczych. Drugą były plany regulacyjne miast lub części miast. Natomiast trzecią stanowiły kartografika przygotowywane w związku z lokacją nowych ośrodków.

Najstarsze zachowane plany miast Królestwa Polskiego doby konstytucyjnej powstały w pierwszych latach jego istnienia, jeszcze przed ustanowieniem w 1818 r. urzędu dozorców miast i przed wydaniem w następnym roku pierwszej instrukcji w sprawie sporządzania map. Do tej grupy należą m.in. plany wykonane w 1816 r. w związku z projektowaniem rewirów dla ludności żydowskiej: Ciechanowa ${ }^{8}$, Pułtuska (ryc. 2) ${ }^{9}$ i Wyszogrodu ${ }^{10}$. Dwa z nich to odręczne

${ }^{6}$ Na temat liczby miast i jej zmian w okresie Królestwa Kongresowego: Kołodziejczyk R. 1961, s. $192-194$.

Kieniewicz S. 1956, s. 17-24. Kartografika miejskie z badanego okresu są obecnie rozproszone w zasobach kilku archiwów polskich, por.: Plany. 1996. Plan Grójca z 1833 r. znajduje się z kolei w Centralnym Państwowym Historycznym Archiwum w Petersburgu, Omilanowska M. 2003, nr 62.

${ }^{8} \mathrm{AGAD}, \mathrm{KiO}, 83$.

9 AGAD, KRSW, 4482, k. 17.

${ }^{10}$ AGAD, KiO, 122. 
szkice, bez podziałki liniowej, natomiast plan Wyszogrodu przygotowano w skali ok. 1:2000. Mapy miast Królestwa Polskiego, które powstały przed wejściem w życie 28 marca $1823 \mathrm{r}$. instrukcji Komisji Miast KRSWiP, były sporządzane w różnych skalach, najczęściej ok. 1:1000, np. plan sytuacyjno-regulacyjny Błonia z 1820 r. (zachowany w kopii z 1827 r.), autorstwa budowniczego obwodu gostyńskiego Michała Grabskiego ${ }^{11}$ i plan sytuacyjno-regulacyjny Tarczyna z 1822 r. geometry Józefa Bojarskiego ${ }^{12}$. Przed rokiem 1823 wykonywano mapy także w skali 1:1500. Taką skalę zastosował w 1818 r. m.in. geometra i budowniczy Jan Medyński, na Planie sytuacyjnym miasta Sochaczewa ${ }^{13}$. Natomiast po 1823 r. większość tego typu map wielkoskalowych miast Królestwa Polskiego, zarówno sytuacyjnych, jak i sytuacyjnoregulacyjnych, była wykonywana w przepisowej skali 1:1500. Wówczas powstały m.in.: mapa Gąbina z 1823 r., autorstwa inżyniera województwa mazowieckiego Ignacego Sternberga, z naniesionym projektem osady sukienniczej ${ }^{14}$, mapa Grójca z 13 października 1829 r., autorstwa geometry przysięgłego Królestwa Polskiego, Augustyna Sulikowskiego ${ }^{15}$, ponadto mapa sytuacyjno-regulacyjna Łowicza z 1825 r. nieznanego autora ${ }^{16}$ i mapa sytuacyjno-regulacyjna Płocka z roku 1835/1836 Joachima Łuszczewskiego ${ }^{17}$. W tym czasie opracowywano także mapy miast i okolic w skali ok. 1:5000. Zachowała się m.in. mapa sytuacyjna miasta Sieradza i jego okolic z 1821 r., autorstwa geometry Ignacego Szeffera, w skali ok. 1:5300 ${ }^{18}$.

Wśród wielkoskalowych map miast Królestwa Polskiego wykonanych na podstawie instrukcji Komisji Miast należy wyróżnić przed wszystkim te, które są przykładem skrupulatnej realizacji zaleceń KRSWiP. W zbiorach archiwalnych znajduje się niewiele „kompletów” map złożonych z planu miasta w granicach zabudowy w skali 1:1500 oraz mapy miasta i jego gruntów w skali 1:5000. Miał na to wpływ głównie stopień realizacji przez poszczególne ośrodki postanowień władz państwowych, z drugiej zaś stan zachowania kartografików. Do nielicznych miejscowości, w których skrupulatnie zrealizowano owe zalecenia, należał Szadek. Mappa pomiarowa terytorium miasta powiatowego Szadek sporządzona w 1824 r. przez mierniczego przysięgłego i patentowanego Wilhelma Bergemanna (ryc. 3$)^{19}$ całkowicie odpowiada wymogom instrukcji z roku 1823. Została wykonana w skali ok. 1:1500 na karcie papierowej o wymiarach $118,8 \times 99 \mathrm{~cm}$, w orientacji północno-wschodniej. Na planie zaznaczono zabudowania miejskie i należące do folwarku rządowego Szadek, sieć hydrograficzną, drogową i uliczną (z podaniem nazw ulic), ogrody, łąki, wiatraki i młyn wodny. Legenda pozwala na rozróżnienie zabudowy drewnianej i murowanej oraz identyfikację rodzajów własności: rządowej, kościelnej, miejskiej i żydowskiej. Śladem zmian w zagospodarowaniu przestrzennym miasta są także zaznaczone na planie obiekty wojskowe: stajnie i ujeżdżalnia oraz place, na których stały budynki rozebrane z rozkazu „komisarza fabrycznego”. Egzemplarz planu Bergemanna przechowywany w Archiwum Głównym Akt Dawnych w Warszawie (dalej cyt.: AGAD) służył do prowadzenia dalszych prac kartograficzno-geodezyjnych, o czym świadczą naniesione nań projekty regulacji istniejących dróg i wytyczenia nowych. Przewidywano m.in. wyprostowanie ulicy Wilamowskiej, przedłużenie ulicy Warszawskiej oraz wyznaczenie rynku i nowych ulic we wschodniej części miasta, gdzie miała powstać osada fabryczna. Było to związane z podjętymi w latach

${ }^{11}$ AGAD, Zb. Kart., 46-2.

12 AGAD, Zb. Kart., 369-9.

13 AGAD, KRSW, 1839, k. 176.

14 AGAD, Zb. Kart., 198-13.

15 AGAD, Zb. Kart., 195-18.

16 Zachował się jedynie odrys tej mapy sporządzony w 1935 r. i przechowywany w zbiorach kartograficznych Politechniki Warszawskiej, zob.: PW, WA, Zb. Kart., U III 65.

17 Staszewski K. 1938, s. 12-13.

${ }_{18}$ AGAD, Zb. Kart., 486-18.

19 AGAD, Zb. Kart., 184-3. 


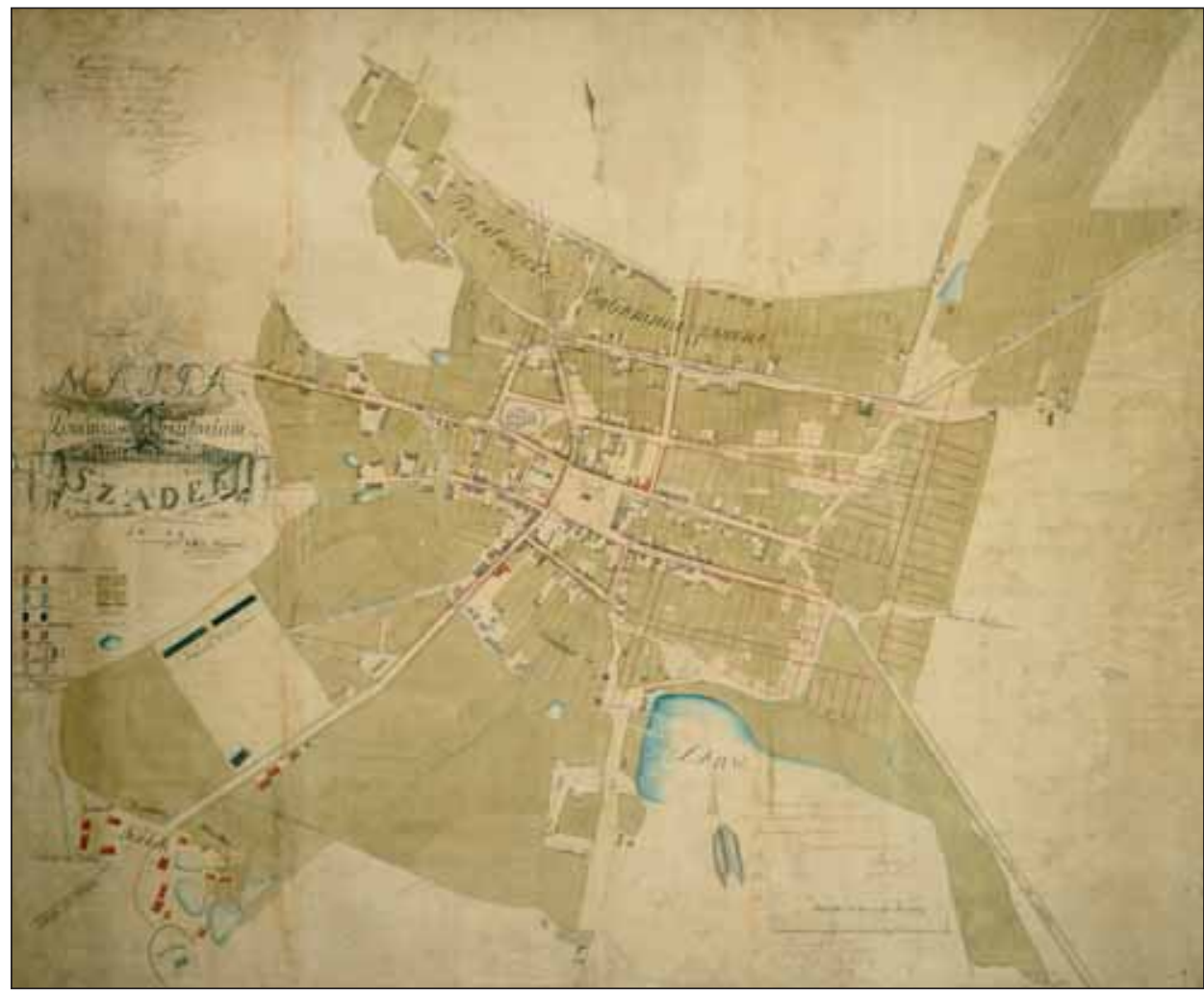

Ryc. 3. Plan sytuacyjno-regulacyjny Szadka, 1824 r. (AGAD, Zb. Kart. 184-3)

Fig. 3. A situation-regulation plan of Szadek, 1824 (AGAD, Zb. Kart. 184-3)

dwudziestych XIX w. działaniami rządu Królestwa Polskiego zmierzającymi do rozbudowy przemysłu, głównie włókienniczego. Szadek, oprócz m.in. Zgierza i Gąbina, był w grupie miast, w których planowano założenie osad rzemieślniczych, stworzenie ośrodków wyrobu tkanin wełnianych. W Szadku realizacja tych planów doprowadziła do powstania Nowego Miasta, a właściwie regulacji (wyprostowania) ulic we wschodniej części dawnego miasta lokacyjnego, na których zamknięciu założono nowy rynek, mający stanowić centrum nowej dzielnicy ${ }^{20}$. W 1826 r. Wilhelm Bergemann sporządził, zgodnie z instrukcją wydaną przez Komisję Miast, drugą mapę, tym razem okolic Szadka, przedstawiającą grunty miejskie. Mappa pomiarowa realności do miasta Szadek należacych ${ }^{21}$ jest rękopisem wielobarwnym, sporządzonym na karcie papierowej o wymiarach $112,7 \times 160,2 \mathrm{~cm}$, w skali 1:5000, w orientacji północno-zachodniej (ryc. 4). Na planie naniesiono granice posiadłości miejskich, wyróżniono grunty orne,

${ }^{20}$ O skutkach dla rozwoju przestrzennego miasta próby założenia w Szadku osady fabrycznej informuje rękopiśmienna redukcja mapy Szadka z 1824 r. Wilhelma Bergemanna, sporządzona po 1837 r. Kopię odróżnia od oryginału skala $(1: 5000)$, wymiary $(57,5 \mathrm{x} 45,0 \mathrm{~cm})$ oraz zaznaczenie zmian w układzie przestrzennym miasta, które nastąpiły w ciągu kilkunastu lat: ulica Wilamowska na wschodnim odcinku występuje w dwóch wersjach — starej i nowej, zgodnej z projektem regulacji, ulica Warszawska została przedłużona. Widoczne są również nowo wytyczone ulice: Ogrodowa, Wodna i Fabryczna oraz Nowy Rynek, AGAD, Zb. Kart., 323-25; Bartoszewicz A. 2008, s. 87-88.

${ }^{21}$ AGAD, Zb. Kart., 195-20. 
ogrody, łąki, lasy, ponadto wiatrak, cegielnię i cmentarz katolicki. Natomiast samo miasto i jego zabudowę pominięto ${ }^{22}$. Opisaną dokumentację przygotowano, mimo że władze miejskie dysponowały wówczas imponującym dziełem kartograficznym z okresu pruskiego, tj. wielobarwną mapą rękopiśmienną wykonaną na karcie papierowej podklejonej na płótnie, o wymiarach $118 \times 145 \mathrm{~cm}$, o orientacji północnej, w skali ok. 1:5000. Plan von der gehaltenen speciellen Vermessung der königlichen immediat Stadt Szadek został wyrysowany w 1808 r. przez konduktora pruskiego J.A. Weicherta, na podstawie pomiarów w latach 1805-1806 ${ }^{23}$.

Stan zachowania kartografików miejskich z terytorium Królestwa Polskiego z lat 1823-1836 nie pozwala na ustalenie liczby miast, które w pełni zrealizowały instrukcję z $1823 \mathrm{r}$. w okresie jej obowiązywania. Przechowywane w polskich zbiorach archiwalnych mapy wielkoskalowe, zarówno oryginały, jak i kopie umożliwiają jedynie stwierdzenie, że obecnie dysponujemy (oprócz Szadka) kompletami dwóch map w skali ok. 1:1500 i ok. 1:5000 dla 22 miast: Błonia, Brdowa, Czeladzi, Częstochowy, Dąbia (pow. kolski), Kozienic, Krasnegostawu, Łaskarzewa (pow. garwoliński), Łęczycy, Małogoszczy, Mstowa (pow. częstochowski), Pajęczna, Piotrkowa Trybunalskiego, Radomia, Radomska, Skierniewic, Szydłowca, Szydłowa, Tarczyna, Wiżajn (pow. suwalski), Wolborza i Zgierza. Z tego okresu zachowały się także plany 19 miast w skali ok. 1: 1500: Białej Podlaskiej, Bolimowa, Gąbina, Grójca, Janowa Podlaskiego, Jeżowa (pow. brzeziński), Łowicza, Mszczonowa, Olsztyna (pow. częstochowski), Piaseczna, Płocka, Przyrowa (pow. częstochowski), Raciążka, Radziejowa, Rzgowa (pow. łódzki), Skaryszewa (pow. radomski), Solca (pow. sandomierski), Szczercowa (pow. łaski) i Wąwolnicy. Ponadto w zbiorach polskich znajduje się 31 map miast i ich okolic z lat 1823-1836 wykonanych w skali ok. 1:5000 oraz w skali ok. 1:4800 lub ok. 1:4200 (dwie ostatnie skale stosowali wówczas kartografowie wojskowi): Bolesławca, Dubienki (pow. hrubieszowski), Goszczyna (pow. grójecki), Jastrzębia (pow. radomski), Jedwabnego, Jędrzejowa, Kalisza, Kazimierza (pow. słupecki), Kielc, Kłodawy, Krośniewic, Krzepic, Lądka (pow. słupecki), Lublina, Łodzi, Nieszawy, Pabianic, Pawłowa (pow. hrubieszowski), Piątka, Przedborza (pow. sandomierski), Pułtuska, Radzymina, Sieciechowa (pow. radomski), Sieradza, Tomaszowa Mazowieckiego, Turka, Uniejowa, Widawy (pow. sieradzki), Wielunia, Wiskitek, Włocławka i Włodawy ${ }^{24}$.

Dwie z nich — mapy Nieszawy i Widawy zasługują na szczególną uwagę, ponieważ zostały opracowane przez wojskowe służby topograficzne armii Królestwa Polskiego, które rzadko zajmowały się kartowaniem terenów miejskich (nie licząc map wielkoskalowych Warszawy). Mapa Włodawy jest dziełem pięcioarkuszowym, wykreślonym w 1826 r. przez oficerów Biura Topograficznego Korpusu Inżynierów Wojskowych, na podstawie pomiaru wykonanego rok wcześniej. Składa się z arkusza zbiorczego w skali ok. 1:16800 i czterech arkuszy w skali ok. 1:4200 ${ }^{25}$. Z kolei sześcioarkuszowa mapa Nieszawy sporządzona została po roku 1826, wedle pomiaru przeprowadzonego w 1824 r. przez oficerów Sztabu Kwatermistrzostwa Generalnego — pułkownika Michała Pełczyńskiego oraz poruczników Wincentego Horiana i Ludwika Hoffmana, także w skali 1:4200. Do grupy miejskich kartografików „wojskowych” można zaliczyć również mapy miasta-twierdzy Zamościa. Wśród 19 zachowanych planów tego ośrodka z lat 1815-1830 przeważają materiały kartograficzne w skalach 1:2000-1:4800. Autorem lub współautorem większości z nich był dowódca Korpusu Inżynierów Wojskowych, generał brygady Jan Chrzciciel Mallet ${ }^{26}$. Najbardziej reprezentatywne dla kartografii Zamościa z omawianego

22 Drugi egzemplarz tej mapy znajduje się w Archiwum Państwowym w Poznaniu, Bartoszewicz A. 2008, s. $88-89$.

${ }^{23}$ AGAD, Zb. Kart., 486-19; Bartoszewicz A. 2008, s. 86.

24 Plany. 1996; Bartoszewicz A., Bartoszewicz H. 2012, s. 35; Bartoszewicz H. 2012, s. 105-110.

25 AGAD, Zb. Kart., 69-21, ark. 1-5.

26 Żygawski J., Sirko M. 2006, s. 238-241. 


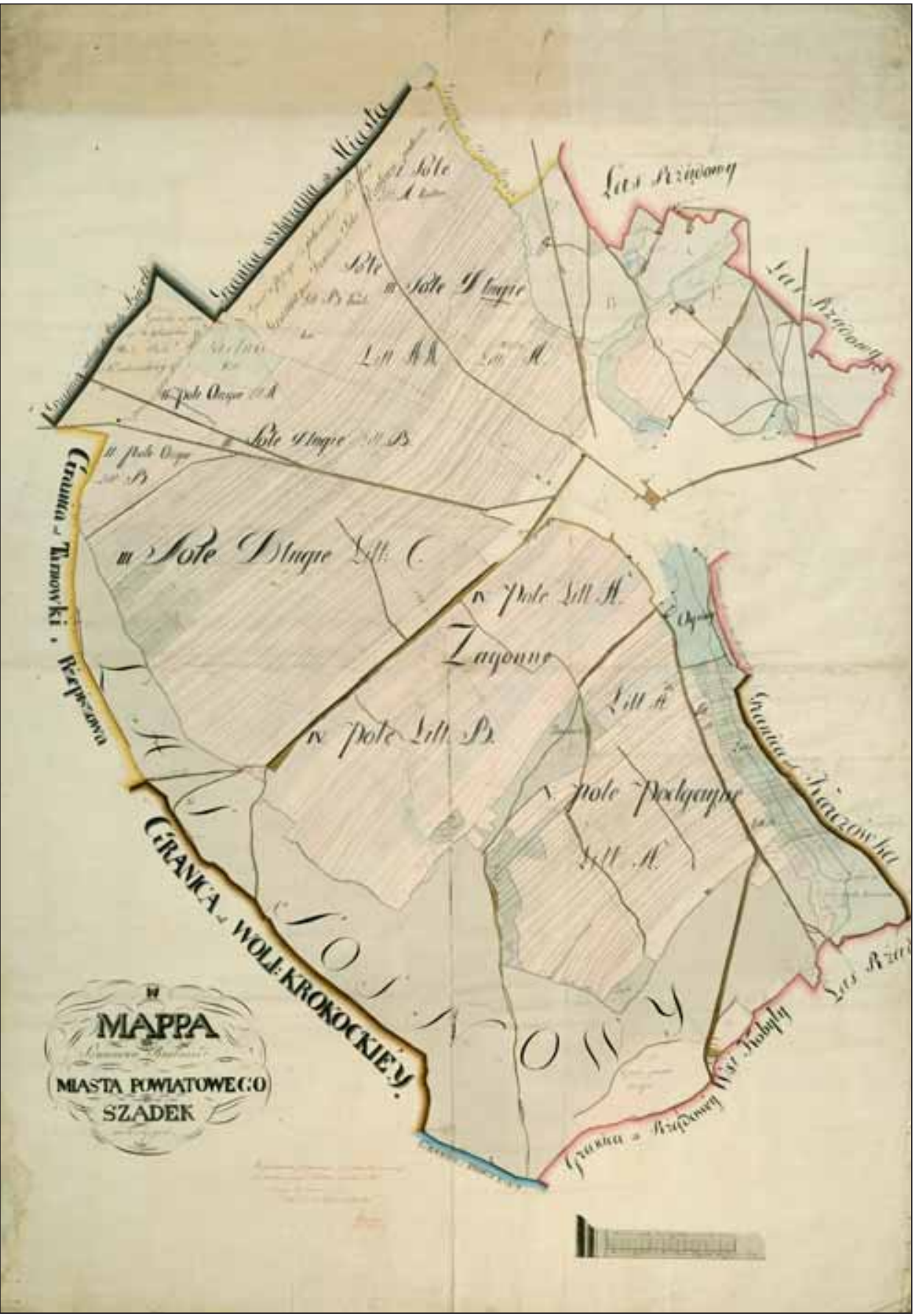

Ryc. 4. Mapa własności ziemskiej Szadka, 1826 r. (AGAD, Zb. Kart. 195-20)

Fig. 4. A map of real estate in Szadek, 1826 (AGAD, Zb. Kart. 195-20) 
okresu są: wykonany 20 grudnia 1825 r. przez Malleta, Plan des projets des fortifications sur la place de Zamość w skali ok. 1:170027 i Plan de la place Zamość z 1818 r., autorstwa podpukkownika Leonarda Jodko, opracowany w skali ok. 1:500028. Obie mapy zostały przygotowane w skali zbliżonej do przewidzianej w instrukcji z 1823 r., a zarazem to dzieła wysokiej jakości zarówno pod względem dokładności pomiaru, jak i jakości wykonania rysunku.

Większość planów regulacyjnych sporządzonych w latach 1815-1836 powstała w związku z poszerzaniem ulic oraz usuwaniem zabudowy z rynków i tworzeniem w ten sposób otwartych placów, które jednocześnie traciły swe dotychczasowe funkcje handlowe (targowiska przenoszono na obrzeża miast). Obserwowano również odwrotne tendencje — zmierzające do zmniejszenia powierzchni rynku. Przyczyną takich działań była chęć dostosowania rozmiaru placu do wielkości miasta bądź stworzenie nowego bloku zabudowy, pozwalającego na wzniesienie ratusza i budynków towarzyszących. Plany regulacyjne wykonywano wówczas również na potrzeby prac podejmowanych w celu poprawy warunków komunikacyjnych i higienicznych. Kierowano się również względami estetycznymi. Przykładem może być Plan nowo projektowanego wjazdu do miasta Lublina na trakcie głównym z Warszawy z 1820 r. autorstwa Łukasza Rodakiewicza, w skali ok. 1:1500 ${ }^{29}$. W tym czasie często przeprowadzano regulacje także w związku z otaczaniem miast wałami (okopami), aby ograniczać wjazd i umożliwiać pobieranie przy rogatkach opłat miejskich za przywożone produkty. Okopy te odgrywały także rolę sanitarną, chroniąc $\mathrm{w}$ pewnym stopniu ośrodki przed epidemiami ${ }^{30}$.

Projekty regulacyjne w latach 1815-1836 sporządzano także dla części miast przeznaczanych na rewiry (dzielnice) dla ludności żydowskiej ${ }^{31}$. W tej grupie zachowanych kartografików istotne są trzy, wymienione poniżej plany, ponieważ obejmują zasięgiem znaczną część miasta, powstały na postawie dokonanego wcześniej pomiaru i wykreślono je z dużą dokładnością. Pierwszy z nich to plan regulacyjny części Węgrowa, w skali ok. 1:2000, sporządzony w lipcu 1822 r. przez budowniczego obwodu siedleckiego, Adolfa Mateusza Dowkontta ${ }^{32}$. Drugi opracował w 1823 r. Stefan Koźmiński. To Plan sytuacyjny części miasta powiatowego Łosic stosownie do planu restauracji z projektem odosobnienia Żydów między czerwonymi liniami, w skali ok. 1:1500 33 . Trzeci zaś to Plan sytuacyjny rewiru, w którym Żydzi budować i zamieszkiwać mają, w mieście obwodowem Wieluniu, który został sporządzony w 1823 r., w skali ok. 1:1500 na podstawie pomiarów Ferdynanda Bergemanna. Autorem projektu regulacji był budowniczy obwodu piotrkowskiego Jan Daniel Nikol ${ }^{34}$.

W omawianym okresie powstało niewiele projektów urbanistycznych i planów regulacyjnych całych miast. W zbiorach Archiwum Państwowego m.st. Warszawy zachował się opracowany w 1817 r. przez Jakuba Kubickiego regulacyjny plan miasta Pragi z wykreśloną w całości nową siecią placów i ulic. Autor planu, wybitny architekt i urbanista ${ }^{35}$, przedstawił projekt sieci komunikacyjnej i zabudowy, który miał być zrealizowany po wyburzeniu pozostałości fortyfikacji z czasów Księstwa Warszawskiego. Podstawowy element regulacji Pragi stanowiło odnowienie okopu wytyczającego jej granice od roku 1770. Kubicki pozostawiał także główny trakt południe-północ: ówczesne ulice Wołową i Targową oraz ulice Brukową i Ząbkowską. Zlikwidował natomiast ulicę Szeroką, zachowując dwa zasadnicze wyloty rogatkowe

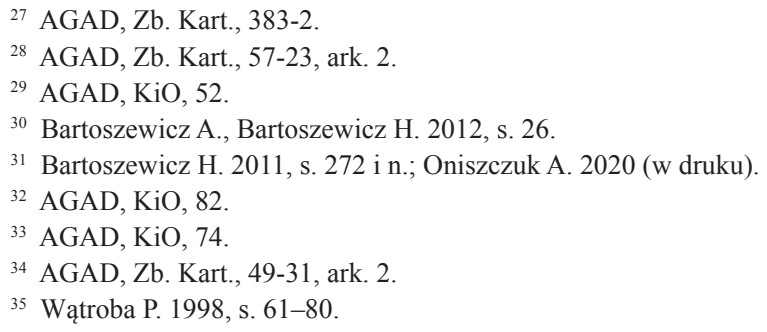


traktów, tj. południowy (Grochowski) i północny (Golędzinowski). Oprócz rogatek Grochowskich, Ząbkowskich i Golędzinowskich przewidział też czwarte — Mostowe, leżące na osi nowo projektowanej przeprawy, u wylotu ulicy Mostowej. Głównymi osiami projektu Kubickiego było pięć ulic rozchodzących się promieniście, stanowiących główne arterie Pragi. Architekt zaprojektował również liczne place — cztery duże targowe, dwa o charakterze reprezentacyjnym oraz plac „przedmostowy” i niewielkie zlokalizowane przy każdej z rogatek. Jego dziełem są także projekty gmachów państwowych, administracyjnych, kościelnych, zakładów użyteczności publicznej, budynków handlowych oraz licznych obiektów wojskowych. W północnej części Pragi umieścił dzielnicę żydowską ${ }^{36}$. Plan regulacyjny Pragi Kubicki wpisał w jednolity układ urbanistyczny z lewobrzeżną Warszawą. Powiązał go również ze swoimi planami przebudowy Zamku Królewskiego i regulacji terenów wokół niego, które powstały w tym samym czasie $^{37}$. Zarówno plan regulacyjny Pragi z 1817 r., jak i będący jego przeróbką projekt z $1828 \mathrm{r}$. nie zostały zrealizowane. Jednak w latach dwudziestych i trzydziestych XIX w. w prawobrzeżnej części Warszawy wytyczono nową sieć ulic, którą połączono z powstającymi wówczas traktami, łączącymi Warszawę z północnymi i wschodnimi ziemiami Królestwa Polskiego ${ }^{38}$.

Plany regulacyjne były tworzone także w związku z translokacją miast. Interesujące są dzieje powstania map wielkoskalowych Ryczywołu. Zostały one opracowane nieco wcześniej, bo w okresie Księstwa Warszawskiego, na potrzeby projektu przeniesienia tego lokowanego w drugiej połowie XIV w. ośrodka ${ }^{39}$. Prace inwentaryzacyjne i planistyczne trwały kilka lat. Projekt założenia nowego miasta, datowany 11 lutego $1811 \mathrm{r}^{40}$, opracował budowniczy departamentu radomskiego, Józef Sadkowski. Autor ten wykonał także projekty ratusza, domów mieszkalnych ${ }^{41}$, kaplicy ${ }^{42}$ i poczty ${ }^{43}$ w translokowanym mieście. Ten szeroko zakrojony plan okazał się jednak zbyt kosztowny i nie został zatwierdzony do realizacji. Kolejny projekt przygotował geometra Księstwa Warszawskiego Tomasz de Wiernek (Wernicke). W 1813 r. najpierw sporządził plan inwentaryzacyjny miasta ${ }^{44}$, a następnie projekt nowego założenia Ryczywołu ${ }^{45}$, który został zaaprobowany przez władze państwowe (1 listopada 1813 r.). Upadek Księstwa Warszawskiego spowodował, że i tego projektu nie urzeczywistniono. Jednakże plan autorstwa Wierneka, skromniejszy pod względem przestrzeni i zabudowy w porównaniu z projektem Sadkowskiego, był podstawą opracowania nowej koncepcji przeniesienia Ryczywołu, zatwierdzonej już przez władze Królestwa Polskiego (KRSWiP) w 1818 r. i zrealizowanej przed rokiem 1824. Nowe założenie prezentuje mapa miasta i okolic z 1826 r. sporządzona przez kartografów wojskowych na postawie pomiarów, które przeprowadzili w 1824 r. oficerowie Kwatermistrzostwa Sztabu Generalnego armii Królestwa Polskiego, podpułkownik Franciszek Kozakowski i podporucznik Daniel Tolkemith oraz konduktor Ignacy Lipiński ${ }^{46}$.

36 APW, Zb. Kart., K-20; Szwankowski E. 1948, s. 161-166; Grabiszewska L. 2013, s. 72-74

37 Szerzej na ten temat zob.: Bartoszewicz H. 2017, s. 28-30.

38 Bartoszewicz H. 2017, s. 49-50.

39 Berdecka A. 1974, s. 607. Miejscowość bowiem założona na niskim zalewowym brzegu Wisły u ujścia Radomki ciągle narażona była na powodzie, z których ta z roku 1808 zniszczyła lub uszkodziła wszystkie zabudowania w mieście. W $1811 \mathrm{r}$. postanowiono przenieść ośrodek o ok. $2 \mathrm{~km}$ na południowy zachód od miasta lokacyjnego, na wysoki brzeg rzeki.

40 AGAD, KRSW, 2816, s. 105.

41 AGAD, KRSW, 2816, s. 185.

42 AGAD, KRSW, 2816, s. 124.

43 AGAD, KRSW, 2816, s. 195.

44 AGAD, KRSW, 2816, s. 183.

45 AGAD, KRSW, 2816, s. 184.

${ }^{46}$ AGAD, Zb. Kart., 69-20, ark. 1-5. Zachowała się tylko część arkuszy (pięć) tej wielosekcyjnej mapy Ryczywołu i okolic. 
Spośród map wielkoskalowych z okresu Królestwa Polskiego doby konstytucyjnej na szczególną uwagę zasługują plany miast wówczas lokowanych, ponieważ są to najstarsze zachowane tego typu kartografika polskie. Duży wpływ na rozwój sieci miejskiej, zwłaszcza w zachodniej części Królestwa Polskiego, miały inwestycje w przemyśle, głównie włókienni$\operatorname{czym}^{47}$. W latach 1815-1830 sześć miejscowości położonych na tym obszarze otrzymało prawa miejskie, w tym pięć w województwie mazowieckim: Aleksandrów (Łódzki), Babiak, Konstantynów, Ozorków, Tomaszów Mazowiecki oraz jedna w województwie kaliskim — Zduńska Wola $^{48}$. Najstarszą z takich zachowanych map jest plan Babiaka, lokowanego na przełomie 1815 i 1816 r., sporządzony w maju 1816 r. przez geometrę Antoniego Wańkowskiego, w skali ok. 1:4000. Oznaczono na nim granice miasta i działek (z podaniem ich numerów własnościowych) oraz zabudowę, a także wykreślono sieć komunikacyjną: ulice (z uwzględnieniem ich nazw), trakty (ze wskazaniem ich kierunków), drogi i mosty ${ }^{49}$. Istnieją również trzy mapy wielkoskalowe lokowanej w tym samym czasie miejscowości Ozorków, których autorem jest geometra przysięgły, August Dornstein. Pierwsza z nich, Mapa wsi Ozorkowa, czyli fabryki sukiennej założonej 13 marca 1811 roku, w skali ok. 1:5000, została wykonana 1 lipca 1815 r., czyli $\mathrm{w}$ okresie poprzedzającym nadanie praw miejskich ${ }^{50}$. Druga jest planem lokacyjnym opracowanym w 1816 r., w skali ok. 1:5000, na podstawie przeprowadzonego wówczas pomiaru (ryc. 5) $)^{51}$. Na obydwu kartografikach zaznaczono m.in. obiekty przemysłowe: postrzygalnię, farbiarnię, folusz, cegielnię, tartak, młyn, browar i gorzelnię. Trzecia zaś to mapa sytuacyjna miejscowości, sporządzona także w skali ok. 1:5000, będąca najprawdopodobniej kopią mapy pomiarowej z 1816 r. $^{52}$ Dla założonego dwa lata później Aleksandrowa (Łódzkiego) ${ }^{53}$ zachowała się tylko mapa miasta, którą wykonał w 1821 r. Bernard de Schuttenbach, w skali ok. 1: 4800. Na planie tym oznaczono granice miasta i działek (opatrzono numerami własnościowymi) oraz wykreślono sieć komunikacyjną: ulice (z podaniem ich nazw) i drogi. W założeniu urbanistycznym tego ośrodka zwraca uwagę zagęszczenie działek w śródmieściu. Ogrody zostały usytuowane poza obszarem śródmiejskim ${ }^{54}$. Podobne rozwiązanie można zaobserwować na planie lokacyjnym Zgierza z $1821 \mathrm{r} .{ }^{55}$ Zachowała się ponadto Mappa szczególna terrytoryi przeznaczonego na miasta fabrycznego Zdonska Wola, wykreślona przez W. Bergemanna w roku lokacji tego ośrodka, czyli w $1825^{56}$. Zgodnie z opisem zamieszczonym na planie, stanowi on kopię fragmentu dokumentacji całości dóbr zduńskowolskich, na którą naniesiono jedynie granice nowo lokowanego miasta, bez granic działek i nowej, regularnej siatki ulic.

W latach dwudziestych XIX w. w Królestwie Polskim lokowano miasta nie tylko w zachodniej części państwa. Stanisław Zamoyski, który w 1820 r. otrzymał dobra jadowskie i kołodziąskie jako rekompensatę za Zamość (przejęty przez rząd w celu rozbudowania obiektów fortecznych), trzy lata później uzyskał prawa miejskie dla wsi Jadów w województwie warszawskim, powiecie mińskim ${ }^{57}$. Ocalał plan lokacyjny tego ośrodka, nazwany Projektem do planu na miasto Jadów, wykonany na podstawie pomiaru geometry Goeppnera przed 15 maja

${ }^{47}$ Bajer K. 1958, s. 39-50; Gąsiorowska-Grabowska N. 1975, s. 70 i n.; Kieniewicz S. 1975, s. 56-67.

48 Kieniewicz S. 1975, s. 66-67; Bartoszewicz H. 2012, s. 108-109; Marszał T. 2019, s. 51-58.

49 AGAD, Zb. Kart., 46-1.

50 AGAD, KiO, 7. Ozorków prawa miejskie otrzymał 30 stycznia 1816 r., Katalog. 1974, s. 236-237.

51 AGAD, KiO, 8.

52 APŁ, Zb. Kart., 1583.

53 Tukaj H., Wróbel J. 1992, s. 7; Woźniak K.P. 2017, s. 146-148.

${ }^{54}$ APE, Zb. Kart., 10.

55 AGAD, Zb. Kart., 362-44; APŁ, Zb. Kart., 2650. Zachowała się kopia fragmentu planu lokacyjnego z 1821 , sporządzona w $1841 \mathrm{r}$.

${ }^{56}$ AGAD, Zb. Kart., 488-35.

57 Bartoszewicz A., Bartoszewicz H. 2012, s. 70. 


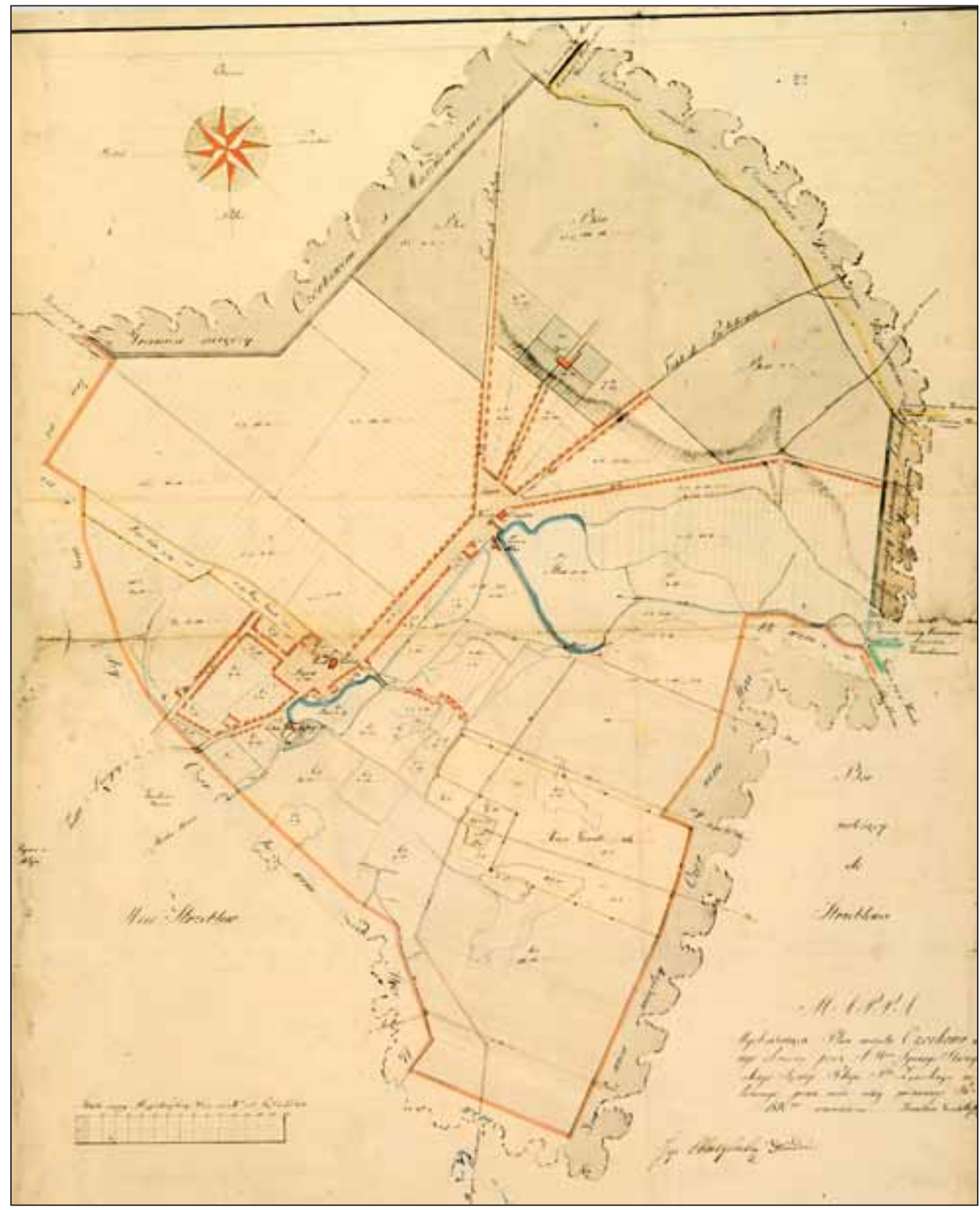

Ryc. 5. Plan lokacyjny Ozorkowa, 1816 r. (AGAD, KiO 8)

Fig. 5. The foundation plan of Ozorków, 1816 (AGAD, KiO 8)

1823 r. W tym samym dniu w Warszawie dokument ten został poświadczony przez H. Rakowskiego. Natomiast 21 maja 1823 r. pieczęć odcisnął na nim i podpis złożył właściciel miasta, Stanisław Zamoyski, zaś 19 sierpnia tegoż roku na posiedzeniu Rady Administracyjnej plan podpisał namiestnik Królestwa Polskiego, generał Józef Zajączek (ryc. 6) ${ }^{58}$.

${ }^{58}$ AGAD, Zb. Kart., 46-8, ark. 1; Bartoszewicz A., Bartoszewicz H. 2012, s. 204-205. 


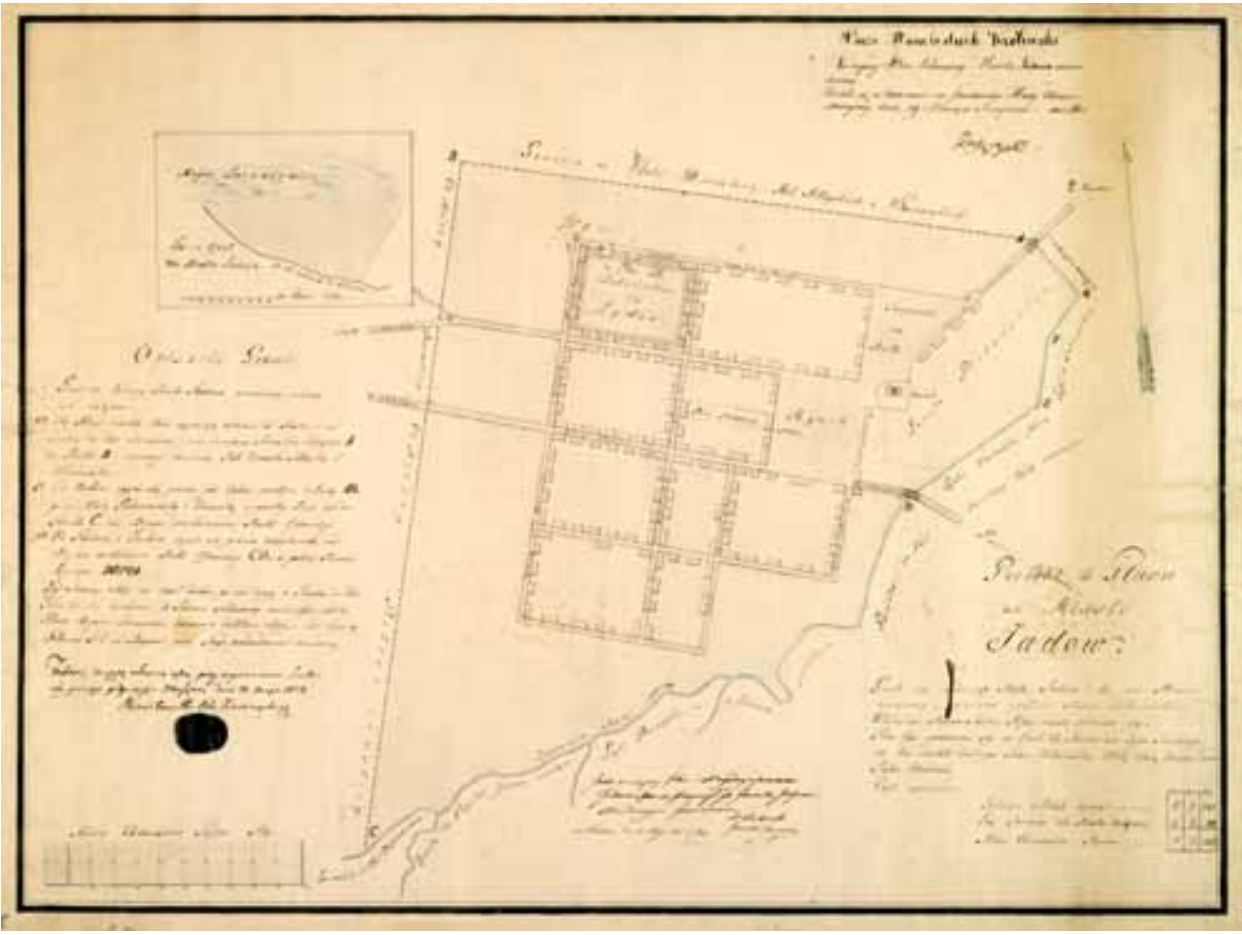

Ryc. 6. Plan lokacyjny Jadowa, 1823 r. (AGAD, Zb. Kart. 46-8, ark. 1)

Fig. 6. The foundation plan of Jadów, 1823 (AGAD, Zb. Kart. 46-8, ark. 1)

Autorzy wyżej wymienionych założeń urbanistycznych wytyczali — o czym już wspomniano - granice projektowanych miejscowości i działek, sieć ulic i placów oraz projektowali tworzącą je zabudowę. Układ nowych miast i osad cechowała regularna, najczęściej prostokątna siatka dróg, stosunkowo duże posesje, niekiedy połączone z ogrodami. Częściej jednak parcele budowlane znajdowały się w centrum, zaś działki ogrodowe poza terenem zabudowanym. Powodowało to zagęszczenie zabudowy i nadawało nowo tworzonym ośrodkom przemysłu włókienniczego w pełni miejski charakter. Centralną część lokowanych miast stanowiły prostokątne place, przy których zazwyczaj wznoszono ratusz, kościół i murowane kramy. Znormalizowane budynki były budowane według typowych projektów dla domów rzemieślniczych, tworząc obraz jednolitego miasta. Powstawały tam również urządzenia niezbędne do produkcji i wykańczania tkanin.

Prace pomiarowe i kartograficzne w latach 1815-1836 na największą skalę były prowadzone w Warszawie, a zadanie to zostało powierzone przede wszystkim wojskowym służbom topograficznym. Od $1815 \mathrm{r}$. podejmowano działania w zakresie planowania rozwoju przestrzennego i przygotowania podstawowych założeń urbanistycznych Warszawy. W 1816 r. opracowano koncepcję uporządkowania i regulacji miasta, złożoną z trzech skoordynowanych planów: 1) inwestycji miejskich, 2) budownictwa prywatnego, oraz 3) inwestycji rządowych. Rok później powołano Radę Budowlaną pod patronatem Stanisława Staszica, której powierzono nadzór nad inwestycjami miejskimi i opiniowanie tych prywatnych. W 1819 r. uporządkowano Hipotekę Miejską, założoną w 1797 r. przez władze pruskie ${ }^{59}$. Prace porządkowe w mieście rozpoczęto

${ }^{59}$ Szczypiorski A. 1964, s. 111-112, 118-119; Kieniewicz S. 1976, s. 45-46. 


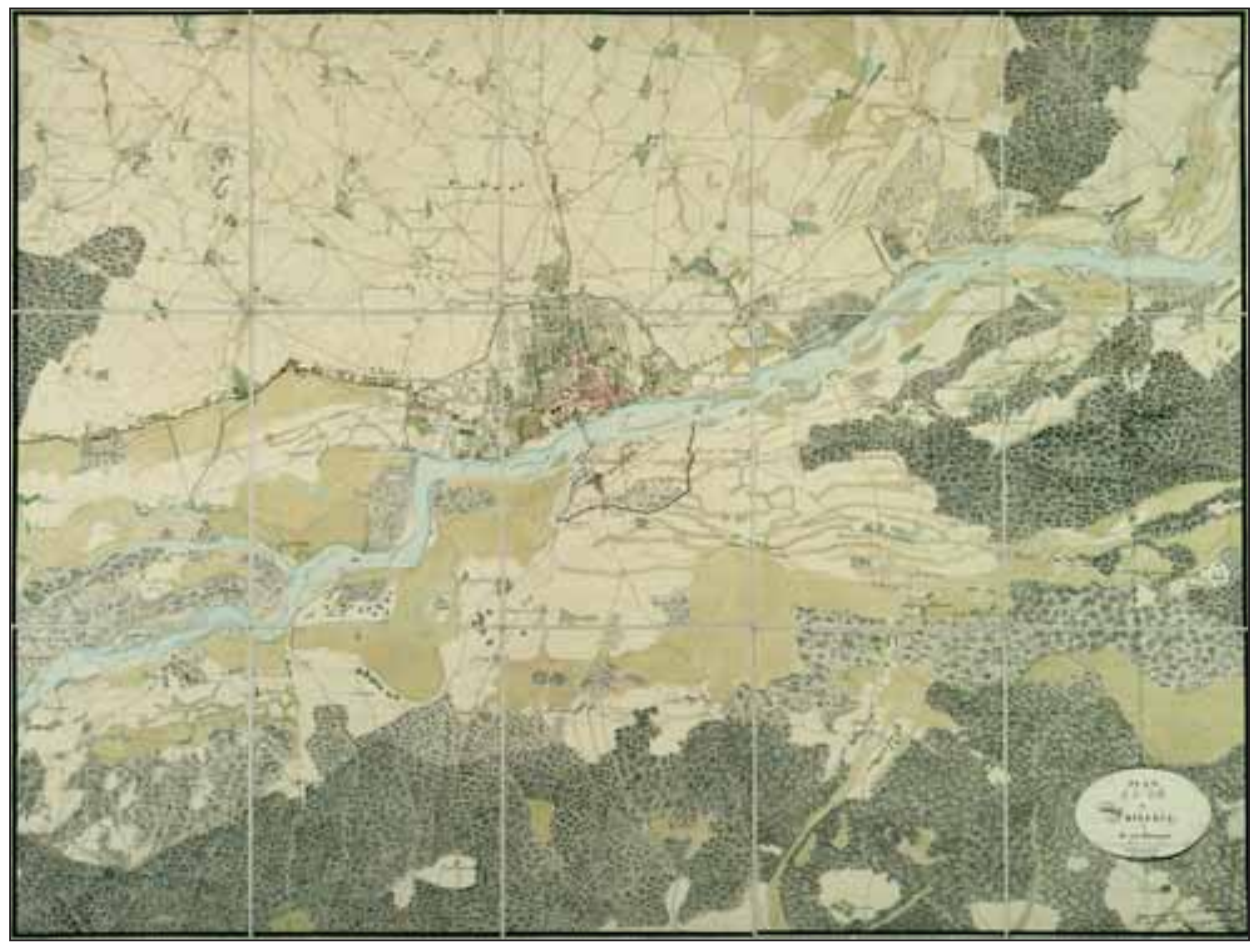

Ryc. 7. Mapa Warszawy i okolic, 1815 r. (AGAD, KiO 590)

Fig. 7. A map of Warsaw and its surroundings, 1815 (AGAD, KiO 590)

w 1815 r. od odbudowy zniszczonego okopu. W tym samym roku zapoczątkowano likwidację fortyfikacji praskiej, zbędnej w nowym układzie politycznym. W 1818 r. okopem otoczono Pragę, która od 1816 r. ponownie stała się oddzielnym miastem. Powstał wówczas omówiony wyżej, pierwszy plan regulacyjny Pragi Jakuba Kubickiego ${ }^{60}$. W latach 1823-1825 powiększono nieznacznie obszar Warszawy w trzech miejscach, włączając na południu część ogrodu Łazienkowskiego, na południowym zachodzie teren pomiędzy ulicami Koszykową i Nowowiejską, oraz kilkanaście posesji przy rogatkach Marymonckich ${ }^{61}$.

Podejmowane prace wymagały dokonania pomiarów miasta oraz sporządzania map wielkoskalowych zarówno jego części, jak i całego terytorium. Zadanie to powierzono powołanemu w 1815 r. Korpusowi Inżynierów Wojskowych, jednej z dwóch jednostek wojskowych służb topograficznych (obok Sztabu Kwatermistrzostwa Generalnego), w ramach której działało Biuro Topograficzne ${ }^{62}$. Dowódcą korpusu został generał brygady Jan Chrzciciel Mallet, autor

${ }^{60}$ Obwód okopu liczył ok. 22 km, obejmując na lewym brzegu obszar niespełna 2000 ha, a na prawym ok. 400 ha, Kieniewicz S. 1976, s. 30.

${ }^{61}$ Obszar Warszawy został powiększony o 80 ha (Krassowski B., Majewska B. 1982). S. Kieniewicz stwierdza, że nowo włączone tereny wynosiły ok. 100 ha (Kieniewicz S. 1976, s. 30).

62 Biurem Topograficznym do 1820 r. kierował ppłk Mikołaj Rouget, a następnie ppłk Józef Koriot. Drugą jednostką wojskowych służb topograficznych, obok Korpusu Inżynierów Wojskowych, był Sztab Kwatermistrzostwa Generalnego z gen. dyw. Maurycym Hauke na czele. Dowodzona przez gen. Hauke formacja wojskowa przygotowała mapy okolic Warszawy, na których jednak obszar miasta stołecznego nie został opracowany, bądź został przedstawiony w znacznie mniejszej skali niż na planach Korpusu Inżynierów Wojskowych. Przedmiotem 
sporządzonego w związku z Kongresem Wiedeńskim planu Warszawy i okolic, uważanego za pierwszą mapę wielkoskalową miasta okresu Królestwa Polskiego (ryc. 7) ${ }^{63}$.

Ważnym czynnikiem rozwoju kartografii w badanym okresie był rozwój szkolnictwa, zarówno wojskowego, jak i cywilnego, kształcącego specjalistów w zakresie miernictwa i kreślenia map. W 1815 r., gdy powstawało Kwatermistrzostwo Generalne i Korpus Inżynierów Wojskowych, kadrę tych jednostek stanowili oficerowie doby napoleońskiej, a niektórzy z nich rozpoczęli służbę jeszcze w wojsku Rzeczypospolitej Obojga Narodów. Oficerowie ci aż do roku 1830 stali na czele tych służb ${ }^{64}$. Jednakże, dzięki działalności dwóch istniejących wtedy szkół wojskowych — Korpusu Kadetów w Kaliszu i Szkoły Elementarnej Artylerii i Inżynierów w Warszawie (przekształconej w 1820 r. w Szkołę Aplikacyjną, najwyższą rangą szkołę wojskową w Królestwie Polskim doby konstytucyjnej), wykształcenie uzyskało liczne grono topografów, którzy poszerzyli kadrę oficerską ${ }^{65}$. Tworzono także szkolnictwo cywilne w zakresie miernictwa. W 1817 r. na Wydziale Nauk i Sztuk Pięknych Uniwersytetu Warszawskiego została ustanowiona Katedra Miernictwa i Rysunków Topograficznych, którą do 1831 r. kierował Juliusz Kolberg. Pod egidą uniwersytetu powstała również w 1823 r. Szkoła Inżynierii Cywilnej. Natomiast w 1825 r. powołano Instytut Politechniczny ${ }^{66}$.

Prowadzone przez Korpus pomiary Warszawy zakończono w latach 1817-1818. Na ich podstawie w 1819 r. Mallet i Józef Koriot sporządzili wielobarwną techniką rękopiśmienną czteroarkuszowy plan miasta w skali ok. 1:240067. W zbiorach AGAD znajduje się tylko jeden z czterech arkuszy, o wymiarach $166,3 \times 131 \mathrm{~cm}$ (ryc. 8 ). Pozostałe trzy przechowywane są w Rosyjskim Wojskowo-Historycznym Archiwum Państwowym w Moskwie ${ }^{68}$. Również w 1819 r. wydano jednoarkuszowy Plan ogólny Warszawy, dzieło Korpusu Inżynierów Wojskowych, w skali ok. 1:19200, stanowiący prawdopodobnie redukcję mapy Malleta i Koriota. Pod dolną ramką znajdują się dwie notatki: z lewej strony — „Wyciśnięto w prasie Sztabu Kwatermi[strzostwa] General[nego] w Warszawie 1819”, z prawej - „Litografowano przez Konduktorów Korpusu Inżynierów" ${ }^{69}$, które wskazują, że był to pierwszy plan miasta stołecznego wykonany techniką litograficzną. Na terenie Królestwa Polskiego była to wówczas nowa metoda odbijania map ${ }^{70}$.

prac Sztabu Kwatermistrzostwa Generalnego były tereny wokół Warszawy, a nie samo miasto, Bartoszewicz A., Bartoszewicz H. 1995, s. 57.

${ }^{63}$ AGAD, KiO, 590. Plan został sporządzony w skali ok. 1:29200. Powstał prawdopodobnie w związku z rozkazem wielkiego księcia Konstantego z 1814 r., który polecił wykonanie dokładnej mapy w Warszawy i jej okolic w promieniu siedmiu mil, w celu przedłożenia jej uczestnikom Kongresu Wiedeńskiego. Mallet polecenie to wykonał, ale wcześniej, między 4 kwietnia a 9 czerwca, zapadły w Wiedniu decyzje dotyczące utworzenia Królestwa Polskiego, Bartoszewicz A., Bartoszewicz H. 1995, s. 59-60.

${ }^{64}$ Gembarzewski B. 1903, s. 55-59, 134-138; Olszewicz B. 1998, s. 84-91; Bartoszewicz H. 2010, s. 28.

${ }^{65}$ Bartoszewicz H. 2010, s. 64-68.

${ }_{66}$ Olszewicz B. 1921, s. 145-146.

${ }^{67}$ AGAD, Zb. Kart., 92-4.

${ }^{68}$ RWHAP, zespół 846, sygn. 21782.

${ }^{69}$ AGAD, Zb. Kart., 77-6.

${ }^{70}$ Litografia - technika druku płaskiego, wynaleziona została w 1796 r., przez mieszkającego w Pradze niemieckiego grafika, Aloisa Senefeldera (1771-1834). Umożliwiała drukowanie z jednej matrycy większych nakładów niż w przypadku akwaforty i miedziorytu. Trafiła do Warszawy stosunkowo szybko, za sprawą młodego, energicznego polskiego lekarza, Jana Siestrzyńskiego (1784-1824) (Domański M. 1996-1997, s. 382-384). Pierwsza pracownia litograficzna w Królestwie Polskim została założona w 1818 r. przez Siestrzyńskiego w pałacu szefa sztabu gwardii królewskiej Aleksandra Chodkiewicza, przy ulicy Miodowej. W grudniu 1818 r. sprowadzony z Monachium drukarz niemiecki, Johann Michael Mettenleiter, zorganizował zakład litograficzny w siedzibie Kwatermistrzostwa Generalnego w pałacu Prymasowskim, przy ulicy Senatorskiej, gdzie urzędowała także Komisja Rządowa Wojny. Prace zakładu nadzorowali oddelegowani do tych czynności oficerowie Kwatermistrzostwa. W następnych latach litografia umożliwiła szybkie odbijanie w dużych nakładach wielkoformatowych, wieloarkuszowych map wielkoskalowych sporządzanych zarówno przez Sztab Kwatermistrzostwa Generalnego, jak i przez Korpus Inżynierów Wojskowych (Olszewicz B. 1921, s. 102). 


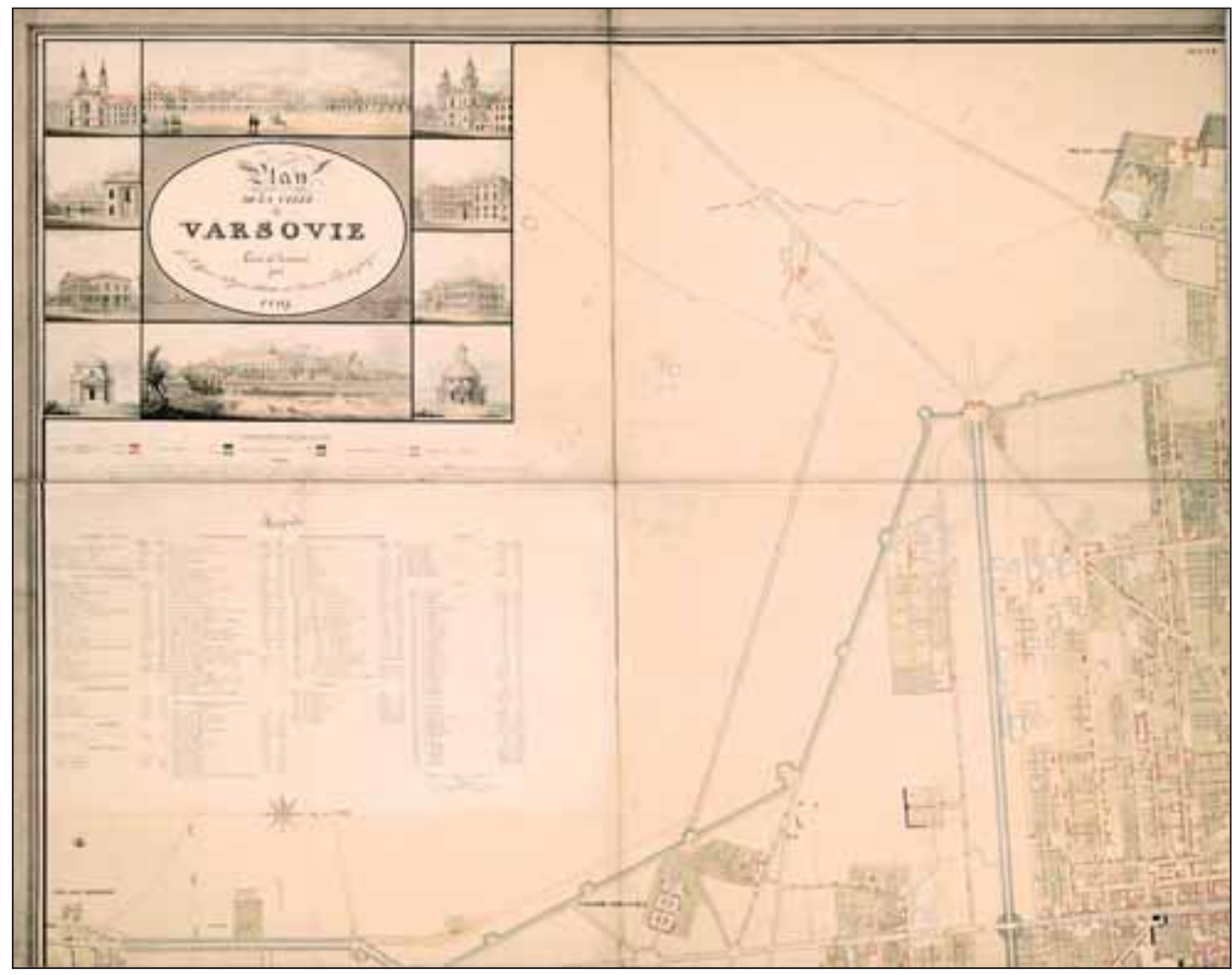

Ryc. 8. Plan Warszawy, 1819 r. (jeden arkusz) (AGAD, Zb. Kart. 92-4)

Fig. 8. A map of Warsaw, 1819 (one sheet) (AGAD, Zb. Kart. 92-4)

Do 1821 r. zakończono pomiary niwelacyjne, które zostały udokumentowane wydaniem pierwszego w historii kartografii polskiej planu przedstawiającego rzeźbę terenu za pomocą warstwic $^{71}$. Plan miasta stołecznego Warszawy obeymuiący domy woyskowe i rządowe z $1821 \mathrm{r}$. wykonany w skali 1:11500, obejmuje zasięgiem lewobrzeżną Warszawę oraz część Pragi. Oprócz ukształtowania terenu w formie warstwic, na planie oznaczono sieć ulic, podając ich nazwy. Natomiast nie ukazano zabudowy, z wyjątkiem zaanonsowanych w tytule budynków wojskowych i rządowych. W części lewobrzeżnej miasta wykreślono także linie wylewu Wisły w latach 1813 i $1816^{72}$.

Zwieńczeniem pomiarów według sieci triangulacyjnej i niwelacyjnych była pierwsza wieloarkuszowa mapa wielkoskalowa Warszawy autorstwa geometrów i kartografów Korpusu Inżynierów Wojskowych. Sporządzony na 25 arkuszach wielobarwny rękopis w skali ok. 1:1200 nie zachował się. Natomiast powszechnie znana jest redukcja mapy, litografowana w skali ok. 1:4800, także w wersji barwionej ręcznie. Dzieło to zasięgiem terytorialnym obejmuje Warszawę, Pragę, Powązki i Czyste, od Belwederu na południu, po rogatki Marymonckie na północy, od wsi Czyste na zachodzie, do rogatek Ząbkowskich na wschodzie. Plan składa się z dziewięciu arkuszy o formacie $51,8 \times 41 \mathrm{~cm}$, numerowanych ręcznie od I do IX ${ }^{73}$. Największym jego walorem jest dokład-

71 Szerzej na temat ówczesnych pomiarów niwelacyjnych oraz metod zastosowanych przy opracowaniu tego planu przez Korpus Inżynierów Wojskowych, zob.: Krassowski, Majewska B. 1982, s. 14-15, $26-27$.

${ }^{72} \mathrm{BN}, \mathrm{ZZK}, 1062$.

73 AGAD, Zb. Kart. 77-5, ark. 1-9. 
ność. Przeprowadzone przez wielu badaczy pomiary, porównywane następnie z Planem miasta stołecznego Warszawy i okolic z 1931 r., pozwalają na stwierdzenie, że średni błąd w przypadku dzieła Korpusu Inżynierów Wojskowych wynosi $+/-7,9$ m, czyli ok. 0,5\% ${ }^{74}$.

Mapa wielkoskalowa Warszawy z 1822 r. uważana jest powszechnie za dzieło doskonałe, jak na czas, w którym powstało. O jej wartości świadczy fakt, że w ciągu 60 lat była wielokrotnie wznawiana, m.in. w latach 1838,1859 , a następnie po zmianie orientacji z zachodniej na północną została wydana w 1885 r. jako tymczasowy plan regulacyjny. To najważniejsze dzieło Korpusu Inżynierów Wojskowych z zakresu kartografii miejskiej jest podstawowym źródłem dla badań nad rozwojem przestrzennym miasta ${ }^{75}$.

Ważnym czynnikiem umożliwiającym stworzenie tak dokładnej mapy wielkoskalowej Warszawy było zastosowanie triangulacji, jako metody pomiaru przestrzeni miejskiej. Zarówno wcześniej, ale także w okresie Królestwa Polskiego, najczęściej pomiary dokonywano metodą stolikową. Pracowali tak m.in. topografowie Sztabu Kwatermistrzostwa, mierząc w 1824 r. obszar Nieszawy i okolic oraz w 1825 r. Włodawy. W latach dwudziestych i trzydziestych XIX w. przy użyciu tej metody dokonano pomiarów także kilku innych dużych miast Królestwa Polskiego, m.in. Płocka. W latach 1835-1836 przeprowadził je geometra, Joachim Łuszczewski, w obrębie miasta i gruntów przyległych, położonych za rogatkami Warszawskimi i Dobrzyńskimi. Na tej podstawie sporządził plan sytuacyjno-regulacyjny w skali 1:1500, do którego wykonał także rejestr pomiarowy ${ }^{76}$.

Spośród map wielkoskalowych Warszawy, stanowiących efekt działalności pomiarowej, kartograficznej i wydawniczej Korpusu Inżynierów Wojskowych, ważne są także dwie prace kartograficzne związane z osobą Józefa Koriota. Pierwsza z nich to plan niwelacyjny miasta stołecznego sporządzony w $1823 \mathrm{r}^{77}$ Druga to plan ogólny Warszawy z 1829 r. Ta ostatnia powstała jako zaktualizowana redakcja planu Korpusu Inżynierów, litografowanego w 1822 r. Zmieniono skalę planu na 1:4200, przystosowując ją do miar rosyjskich, zachowując dwie podziałki liniowe, podane w nowych sążniach polskich i w sążniach rosyjskich. Zasięg planu uległ niewielkiemu powiększeniu w kierunku północnym, w efekcie uwzględnienia obozu wojskowego w Powązkach. Poza tym uaktualniono treść planu, m.in. naniesiono budowany wówczas bulwar nad Wisłą. Nie podano natomiast numerów hipotecznych. Część odbitek litograficznych była ręcznie barwiona ${ }^{78}$.

Na uwagę zasługuje również drugie wydanie planu Warszawy Korpusu Inżynierów Wojskowych z 1822 r., które ukazało się w 1825 r. W zbiorach Muzeum Warszawy znajduje się jego ręcznie kolorowany egzemplarz ${ }^{79}$. W wyniku porównania obydwu wydań tego wybitnego dzieła kartografii warszawskiej można zauważyć spore różnice. Najważniejsze z nich to aktualizacja przebiegu wałów Lubomirskiego — po ich rozszerzeniu w latach 1823-1825 o obszar między ulicami Koszykową i Nowowiejską, na zachód od ulicy Polnej, oraz o tereny położone na południe od Łazienek Królewskich. Na planie z 1825 r. w rejonie Łazienek ukazano koszary Gwardii Huzarów Grodzieńskich oraz „składy siana i słomy dla Pułków Gwar: Koronnych”, których nie ma na planie z 1822 r. Różnice dotyczą także przebiegu Alei Jerozolimskiej, jeszcze wówczas nie opisanej tą nazwą. Na planie z 1822 r. Aleja kończy się od wschodu na skrzyżowaniu z ulicą Nowy Świat, zaś na planie z 1825 r. jest doprowadzona do ulicy Solec. Odmiennie przedstawiono również zabudowę, m.in. w rejonie ulicy Rymarskiej, na obszarze powstającego placu Bankowego, oraz na Marywilu. W przypadku tego ostatniego na planie z $1825 \mathrm{r}$. widoczny jest

74 Krassowski B., Majewska B. 1982, s. 28-29.

75 Bartoszewicz A., Bartoszewicz H. 1997, s. 18-19.

76 Staszewski K. 1938, s. 12-13.

77 IS PAN, Zbiory fotografii i rysunków pomiarowych neg., nr 47803; Weszpiński P.E. 2017, s. 126-127.

${ }^{78}$ AGAD, Zb. Kart., 92-5, ark. 1-9. 
jeszcze zarys dawnego obiektu, jednak w tle linią kropkowaną naniesiono zarys późniejszej zabudowy, czyli zbudowanego w latach 1825-1833 Teatru Narodowego (Wielkiego) ${ }^{80}$.

Kartografia warszawska lat 1815-1836 to także efekt działalności geodetów i kartografów cywilnych. Większość sporządzonych przez nich jednoarkuszowych map wielkoskalowych to mniej lub bardziej wierne przeróbki dzieł Korpusu Inżynierów Wojskowych. Najbardziej wartościowe, oryginalne ich prace to: wykonany przez architekta Leonarda Schmidtnera Plan de Varsovie avec les principaux édiffices de cette capitale, opublikowany $\mathrm{w} 1825 \mathrm{r}^{81}$ i Plan Warszawy sporządzony w 1827 r. przez geodetę i kartografa Juliusza Kolberga ${ }^{82}$. Plan Warszawy Schmidtnera, wydany w skali 1:17900, uzupełnia 67 rysunków ważniejszych budynków, pałaców, kościołów i innych obiektów architektonicznych w skali 1:1300, przygotowanych przez autora z natury. To jedyne dzieło kartograficzne doby konstytucyjnej Królestwa Polskiego, na którym umieszczono sylwetki budowli warszawskich wykonane techniką litograficzną, a zatem inną niż miedzioryty przedstawiające budowle na osiemnastowiecznych planach Pierre Ricaud Tirregaille’a i Giovanni Rizzi Zannoni'ego. Cechą charakterystyczną tej jednoarkuszowej mapy wielkoskalowej jest brak nazw ulic. Natomiast jest to pierwszy cywilny plan, na którym uwzględniono odcinek Alei Jerozolimskiej między Nowym Światem a ulicą Solec, zbudowany w latach 1822-1823. Poza tym, po raz pierwszy umieszczono na mapie wielkoskalowej Warszawy projekt bulwaru nad Wisłą, którego budowę rozpoczęto w roku $1825^{83}$. Na Planie Warszawy J. Kolberga miasto zostało przedstawione w nowych granicach, z przyłączonymi do niego w 1825 r. terenami na południu ${ }^{84}$. Nowymi elementami są również numery cyrkułów, ale bez ich granic. Granice te najprawdopodobniej miały zostać naniesione wielobarwną techniką rękopiśmienną ${ }^{85}$.

Dzięki temu rekonstrukcja ówczesnego podziału administracyjnego Warszawy na podstawie planu J. Kolberga jest możliwa. Nazwy ulic zostały zastąpione na planie numerami powiązanymi ze sporządzonym w układzie alfabetycznym Skorowidzem ulic i domów, obejmującym 261 ulic oraz wykaz posesji — ponad 3100 na terenie lewobrzeżnej Warszawy i 263 na obszarze Pragi ${ }^{86}$.

Polityka władz Królestwa Polskiego zmierzająca do odbudowy miast zaniedbanych po trzecim rozbiorze Rzeczypospolitej przez państwa zaborcze oraz zniszczonych w okresie działań wojennych i przemieszczania się wojsk w latach 1806, 1809 i 1812-1813 była najważniejszym czynnikiem rozwoju polskiej kartografii wielkoskalowej w drugim i trzecim dziesięcioleciu XIX w. Stworzono wówczas podstawy prawne porządkowania i regulacji miast, przewidujące opracowanie planu sytuacyjnego i mapy wielkoskalowej własności ziemskiej każdego z nich. Większość dokumentacji kartograficznej powstałej na mocy instrukcji z 1820 i 1823 r. miała charakter planów sytuacyjnych i sytuacyjno-regulacyjnych. W przypadku miast, które uległy całkowitemu zniszczeniu w wyniku prac fortyfikacyjnych, działań wojennych lub

79 Muzeum Warszawy, MHW7718/Pl.

${ }^{80}$ Weszpiński P. 2017, s. 137-145.

${ }^{81} \mathrm{BN}, \mathrm{ZZK}, 579$.

${ }^{82} \mathrm{BN}, \mathrm{ZZK}, 1247$.

${ }^{83}$ Krassowski B., Majewska B. 1982, s. 38. Informacja podana przez Autorów w przyp. 53 w tej publikacji nie opowiada prawdzie. Na „Plan miasta stołecznego Warszawy obeymujący domy woyskowe i rządowe” plan bulwaru nad Wisłą nie został naniesiony.

${ }^{84}$ BN, ZZK, 1247; Krassowski B., Majewska B. 1982, s. 31. Autorzy tej pracy podają błędnie, że cała ulica Aleje Jerozolimskie została przedstawiona na planie Warszawy Schmidtnera z $1825 \mathrm{r}$. W rzeczywistości Schmidtner doprowadził ją tylko do ulicy Solec.

${ }^{85}$ Krassowski B., Majewska B. 1982, s. 32. Hipotezę tę można uznać za możliwą do przyjęcia.

${ }^{86} \mathrm{BN}, \mathrm{ZZK}, 1247$. 
powodzi i miały zostać odbudowane lub relokowane, sporządzano plany regulacyjne. W okresie Królestwa Polskiego doby konstytucyjnej sporządzano także nowy dla tego obszaru rodzaj kartografików miejskich — plany lokacyjne.

Najbardziej dynamicznie rozwijała się wówczas kartografia Warszawy. Na potrzeby stolicy pracowały wojskowe służby topograficzne, przede wszystkim Korpus Inżynierów Wojskowych. Wykorzystano tu wiedzę i potencjał organizacyjny dowództwa, oficerów i konduktorów korpusu w pracach pomiarowych i planistycznych. Kartowanie Warszawy zbiegło się z zastosowaniem nowych technik - triangulacji i pomiarów niwelacyjnych, które przyczyniły się do tworzenia map wielkoskalowych o dużym stopniu dokładności. W tym czasie zastosowano również dwie nowe techniki odbijania map - litografię i staloryt, z których zwłaszcza ta pierwsza odegrała znaczącą rolę w rozwoju i upowszechnianiu kartografii tego ośrodka. Władze Królestwa Polskiego zadbały również o rozwój szkolnictwa kształcącego przyszłe pokolenia geometrów i kartografów, tworząc katedry miernictwa zarówno na uczelniach wojskowych, jak i cywilnych. W Królestwie Polskim doby konstytucyjnej stworzono w kartografii metody i wzorce, a nawet poszczególne plany obowiązujące niemal do końca XIX w.

Prowadzone w latach 1815-1830 prace pomiarowe, regulacyjne i kartograficzne w miastach Królestwa Polskiego przerwał wybuch powstania listopadowego. W latach trzydziestych, a zwłaszcza czterdziestych i pięćdziesiątych XIX w., liczba wykonywanych map wielkoskalowych, zwłaszcza ogólnych planów urbanistycznych miast polskich, zarówno sytuacyjnych, jak i regulacyjnych, uległa zmniejszeniu. Do 1836 r. obowiązywała instrukcja pomiarowa z 28 marca 1823 r. i na jej mocy w pierwszej połowie lat trzydziestych XIX w. sporządzano miejską dokumentację kartograficzną. Jednakże po $1831 \mathrm{r}$. nastąpiła likwidacja lub ograniczenie działalności instytucji prowadzących aktywność w zakresie pomiarów i kartowania miast. Wraz z likwidacją armii Królestwa Polskiego przestały istnieć służby topograficzne Korpusu Inżynierów Wojskowych i Kwatermistrzostwa Generalnego, które uczestniczyły w pracach urbanistycznych. Ograniczono działalność komórek KRSWiP i Komisji Wojewódzkich (od 1837 r. Gubernialnych) zajmujących się sprawami miast. Kwatermistrzostwo rosyjskiej armii okupacyjnej, które przejęło zadania służb topograficznych armii Królestwa Polskiego, kontynuowało natomiast wydawanie i aktualizację planów Warszawy sporządzonych w latach dwudziestych XIX w. ${ }^{87}$

Adresy Autorów:

prof. dr hab. Agnieszka Bartoszewicz

Instytut Historyczny Uniwersytetu Warszawskiego

Krakowskie Przedmieście 26/28

00-927 Warszawa

abartoszewicz@uw.edu.pl

https://orcid.org/0000-0002-5282-2933

dr Henryk Bartoszewicz

Archiwum Główne Akt Dawnych

ul. Długa 7

00-263 Warszawa

h.bartoszewicz@onet.pl

https://orcid.org/0000-0003-4449-0382

${ }^{87}$ Bartoszewicz A., Bartoszewicz H. 1997, s. 20-21. 


\section{BIBLIOGRAFIA}

\section{Źródla archiwalne}

AGAD [Archiwum Główne Akt Dawnych w Warszawie], KiO [Kartografika z innych Oddziałów AGAD], 7, 8, 52, 74, 82, 83, 122, 590.

AGAD [Archiwum Główne Akt Dawnych w Warszawie], KRSW [Komisja Rządowa Spraw Wewnętrznych i Policji], 1839, 4482, 2816.

AGAD [Archiwum Główne Akt Dawnych w Warszawie], Zb. Kart. [Zbiór Kartograficzny] 46-1, 46-2, 46-8 ark. 1, 49-31 ark. 2, 57-23 ark. 2, 69-20 ark. 1-5, 77-5 ark. 1-9, 77-6, 92-5 ark. 1-9, 184-3, 186-17, 195-18, 195-20, 198-13, 323-25, 347-5b, 362-44, 369-9, 383-2, 486-18, 486-19, 488-35.

APŁ [Archiwum Państwowe w Łodzi], Zb. Kart. [Zbiór Kartograficzny], 10, 1583, 2650.

APW [Archiwum Państwowe w Warszawie], Zb. Kart. [Zbiór Kartograficzny], K-20.

BN [Biblioteka Narodowa], ZZK [Zakład Zbiorów Kartograficznych], 579, 1062, 1247.

IS PAN [Instytut Sztuki Polskiej Akademii Nauk], Zbiory fotografii i rysunków pomiarowych, neg. $\mathrm{nr} 47803$.

Muzeum Warszawy, Zbiory kartograficzne, MHW7718/P1.

PW, WA [Politechnika Warszawska, Wydział Architektury], Zb. Kart. [Zbiór Kartograficzny], U III 65.

RWHAP [Rosyjskie Wojskowo-Historyczne Archiwum Państwowym w Moskwie], Zespół 846, sygn. 21782.

\section{Źródła i opracowania publikowane}

Bajer Karol. 1958. Przemysł włókienniczy na ziemiach polskich od początku XIX wieku do 1939 roku. Zarys historyczno-ekonomiczny, Łódź.

Bartoszewicz Agnieszka. 2008. Obraz kartograficzny Szadku w XIX w., „Biuletyn Szadkowski”, t. 8, s. $85-91$.

Bartoszewicz Agnieszka, Bartoszewicz Henryk. 1995. Plany ogólne Warszawy w Archiwum Głównym Akt Dawnych (1809-1915), „Archeion”, t. XCIV.

Bartoszewicz Agnieszka, Bartoszewicz Henryk. 1997. Plany ogólne Warszawy 1809-1916 w zbiorach Archiwum Głównego Akt Dawnych. Katalog, Warszawa.

Bartoszewicz Agnieszka, Bartoszewicz Henryk. 2012, Kartografia miast Mazowsza i ziemi dobrzyńskiej do końca XVIII wieku, wyd. 2, Warszawa-Pułtusk.

Bartoszewicz Henryk. 2007. Obraz kartograficzny miast polskich w XVII-XIX wieku. Katalog wystawy, Warszawa.

Bartoszewicz Henryk. 2010. Nota wydawnicza, [w:] Atlas de cartes et de plans pour servir à l'intelligence de l'histoire de l'insurrection du peuple polonaise par Mr. Spazier, Leipsic 1833 [Atlas map i planów stużacych zrozumieniu historii powstania narodu polskiego wydany w Lipsku w 1833 r. przez Richarda Otto Spaziera], reprint, Warszawa.

Bartoszewicz Henryk. 2010. Udziat inżynierów i kartografów armii Królestwa Polskiego w wojnie polsko-rosyjskiej 1830-1831, „Geodeta”, nr 11 (186), s. 64-68.

Bartoszewicz Henryk. 2011. Rewiry żydowskie w miastach Księstwa Warszawskiego i Królestwa Polskiego świetle map wielkoskalowych, [w:] Z dziejów kartografii, t. 15: Dawna kartografia miast, red. J. Ostrowski, P.E. Weszpiński, Warszawa, s. 259-287.

Bartoszewicz Henryk. 2012. Z dziejów kartografii Mazowsza i ziem sąsiednich XVII-XX wieku, Warszawa-Pułtusk.

Bartoszewicz Henryk. 2017. Warszawa w okresie Królestwa Polskiego doby konstytucyjnej, [w:] H. Bartoszewicz, P.E. Weszpiński, 1825. Korpus Inżynierów Wojskowych. Plan Warszawy. Plan Miasta Stołecznego Warszawy Wymierzony przez Officerów Korpusu Inżenierów w latach 1818 i 1819 i litografowany przez tychże w roku 1822, Warszawa, s. 9-79.

Berdecka Anna. 1974. Nowe lokacje miast królewskich w Małopolsce w latach 1333-1370: chronologia i rozmieszczenie, „Przegląd Historyczny”, t. 65/4, s. 594-624.

Ćwik Władysław. 2001. „Oswobodziciele wolności” — dozorcy miast Królestwa Polskiego (1818-1821), [w:] Przez tysiaclecia: państwo — prawo — jednostka, Materiały ogólnopolskiej 
konferencji historyków prawa Ustroń 17-20 września 2000 r., red. A. Latyński, M. Mikołajczyk, t. 1, Katowice, s. 139-147.

Domański Michał. 1996-1997. Siestrzyński Łukasz Jan (1784-1824), [w:] Polski Stownik Biograficzny, t. 37, Warszawa-Kraków, s. 382-384.

Gąsiorowska-Grabowska Natalia. 1975. Z dziejów przemystu w Królestwie Polskim 1815-1915, Warszawa.

Gembarzewski Bronisław. 1903. Wojsko Polskie. Królestwo Polskie 1815-1830, Warszawa.

Grabiszewska Liliana. 2013. Działalność urbanistyczna i przepisy budowlane Królestwa Polskiego (1815-1915) w planach regulacji warszawskiej Pragi, „Kwartalnik Architektury i Urbanistyki”, t. 58, z. 3, s. $67-92$.

Katalog. 1974. Katalog rysunków architektonicznych z akt Komisji Rzadowej Spraw Wewnętrznych w Archiwum Głównym Akt Dawnych w Warszawie. Rysunki architektoniczne, plany urbanistyczne, varia z lat 1800-1868, oprac. M. Łodyńska-Kosińska, Warszawa.

Kieniewicz Stefan. 1956. Archiwum Skarbowe w Warszawie, [w:] Straty archiwów i bibliotek warszawskich $w$ zakresie rękopiśmiennych źródeł historycznych, t. 2: Archiwa porozbiorowe i najnowsze, red. K. Konarski, Warszawa, s. 17-24.

Kieniewicz Stefan. 1975. Historia Polski 1795-1918, Warszawa.

Kieniewicz Stefan. 1976. Warszawa w latach 1795-1914, Warszawa.

Kołodziejczyk Ryszard. 1961. Zamiana miast na osady w Królestwie Polskim, „Kwartalnik Historyczny", R. 68, z. 1, s. 191-200.

Krassowski Bogusław, Majewska Barbara. 1982. Plany Warszawy 1815-1831, Warszawa.

Marszał Tadeusz. 2019. Szadkowskie ogłoszenie reklamowe z 1837 roku — asumpt do kilku uwag na temat osadnictwa niemieckiego i rozwoju rzemiosła tekstylnego w Szadku na początku XIX w., „Biuletyn Szadkowski”, t. 19, s. 51-75.

Olszewicz Bolesław. 1921. Polska kartografia wojskowa (zarys historyczny), Warszawa.

Olszewicz Bolesław. 1998. Kartografia polska XIX wieku (przeglad chronologiczno-bibliograficzny), t. 1: Materiaty zebrane w Archiwum Polskiej Akademii Nauk, wyd. W. Wernerowa, Warszawa.

Omilanowska Małgorzata. 2003. Spis rysunków architektonicznych z akt Komitetu Techniczno-Budowlanego Ministerstwa Spraw Wewnętrznych w Centralnym Państwowym Archiwum w St. Petersburu: Królestwo Polskie, Warszawa.

Oniszczuk Aleksandra. 2020. Władze Księstwa Warszawskiego wobec Żydów: debata, ustawodawstwo, praktyka, Wrocław (w druku).

Plany. 1996. Plany miast polskich w archiwach państwowych, oprac. M. Lewandowska, M. Stelmach, pod kier. A. Tomczaka, Warszawa.

Staszewski Kazimierz. 1938. Plany i pomiary miasta Płocka oraz gruntów podmiejskich od roku 1793 do lat ostatnich, Płock.

Szczypiorski Adam. 1964. Ćwierć wieku Warszawy 1806-1830, Wrocław-Warszawa-Kraków.

Szwankowski Eugeniusz. 1948. Kubickiego Plan regulacji Pragi, „Biuletyn Historii Sztuki i Kultury”, R. 10, nr 2, s. 161-166.

Tukaj Helena, Wróbel Janusz. 1992. Aleksandrów Łódzki, Zarys dziejów 1816-1948, Aleksandrów.

Wątroba Przemysław. 1998. Jakuba Kubickiego projekty urbanistyczne dla Warszawy i Pragi: przyczynek do recepcji urbanistycznych idei francuskiego oświecenia, „Rocznik Warszawski”, t. 28, s. $61-80$.

Weszpiński Paweł E. 2017. Plan miasta stołecznego Warszawy Korpusu Inżynierów Wojskowych w skali około1:48000 z 1825 roku, [w:] H. Bartoszewicz, P.E. Weszpiński, 1825. Korpus Inżynierów Wojskowych. Plan Warszawy. Plan Miasta Stołecznego Warszawy Wymierzony przez Officerów Korpusu Inżenierów w latach 1818 i 1819 i litografowany przez tychże w roku 1822, Warszawa, s. 83-226.

Woźniak Krzysztof P. 2017. Aleksandrów i okoliczne wsie w świetle nieznanych źródet z przełomu XVIII i XIX wieku, „Studia z Geografii Politycznej i Historycznej”, t. 6, s. 137-151.

Żygawski Jakub, Sirko Mieczysław. 2006. Okoliczności powstania planów i map Zamościa od XVII do XX wieku oraz sylwetki ich autorów, „Polski Przegląd Kartograficzny”, t. 38, nr 3, s. 233-145. 
The cartographic representation of the towns of the Kingdom of Poland in $1815-1836$

The years1815-1836 were very important for the cartography of Polish towns. As regards the technique of map production, Warsaw stood out against other towns, due to the fact that until the mid-19th c. the capital was mapped by the topographic corps of the army, which had at their disposal the most advanced technologies and the best specialist.

A crucial development for the surveying and mapping of Polish towns was the establishment of the Town Committee within the structure of the Government Commission of Internal Affairs and Police on 4th January 1820. The committee was to supervise surveying and cartographic works. Its clerks prepared a new surveying instruction, published on 2nd September 1820; its next instruction, published on 28th March 1823, was in effect until 1836. It provided for the preparation of two maps of each town, at a scale of 1:1500 and 1:5000.

Most of the large-scale maps prepared in the 1820s and 1830s were situation maps or situation-regulation maps, primarily reflecting data on real estate and development, sometimes with plans of regulating some parts or particular streets. Very few regulation maps of whole towns were produced at that time, an example being "The plan of Praga", with a whole new network of streets and squares.

Of the surviving large-scale maps from the Kingdom of Poland, particular attention is due to maps of those towns that were granted municipal right at that time. The growth of urbanization, especially in the western part of the Kingdom, was greatly stimulated by industrialization, particularly by the development of textile industry. Between 1815 and 1830 municipal rights were granted to six towns of the region: Babiak, Ozorków, Aleksandrów, Zduńska Wola, Zgierz, Konstantynów and Tomaszów Mazowiecki.

Proofread by Izabela Szymańska 